\title{
Determinants of structural heterogeneity in Mexican manufacturing industry, 1994-2008
}

\author{
Raúl Vázquez López
}

ABSTRACT

\begin{abstract}
This article analyses the stagnation of productivity and the increasing structural heterogeneity of Mexican manufacturing industry in the period 1994-2008. Traditional indicators of dispersion are estimated for 200 activity classes, 50 branches and nine divisions of the manufacturing sector; and these corroborate the widening disparity in productive efficiency between globalized activities and traditional industries that has been reported in other papers. The study also provides a more detailed account of the intensification of this trend in the first decade of the present century and the specific characteristics of within-sector heterogeneity. Other results obtained using a shift-share technique show that structural change contributes very little to productivity growth, and that technological progress is concentrated in just a few activities that engage with the domestic economy in a variety of ways. Nonetheless, these activities have weak local linkages and add little value to the content of the goods they make.
\end{abstract} statistics, Mexico 


\section{I}

\section{Introduction}

The pioneering thinkers of the Economic Commission for Latin America and the Caribbean (ECLAC) used a historical-structural methodology to study how relations between the different segments of a nation - economic, political and social — change through time. This led them to highlight the importance of the modes of integration of the different strata of the productive system, along with progress in overcoming productive heterogeneity, for development in Latin American countries. In particular, Furtado (1961) and Pinto (1965 and 1970) pointed out that the modernization of developing and dependent structures does not necessarily diminish productivity gaps between different activities, but can maintain and even increase them.

This observation could explain why in the more advanced countries of Latin America such as Mexico (following its adoption of the "neoliberal" model implemented mainly through economic deregulation, privatization of strategic state industries and trade liberalization), the restructuring of manufacturing industry led to a stratification and polarization of the productive structure and, consequently, caused efficiency gaps between the different industrial sectors to widen (Mortimore and Peres, 2001). In fact, at the microeconomic level, growing asymmetries, in terms of modernization, between a small number of firms involved in global value chains (GVCs) led by transnational corporations (TNCS), and a broad group of small and medium-sized enterprises that were being increasingly left behind, has caused the widening productivity differentials between the different classes of activity to be replicated even within individual sectors (Kupfer and Rocha, 2005).
Against that backdrop, this article pursues several objectives simultaneously. Firstly, it aims to give continuity to and revitalize the structural perspective and debate proposed by Latin American development theory. Secondly, it aims to analyse, for the period 1994-2008, the trend of structural heterogeneity, as defined by this school of thought, in the case of Mexican manufacturing - a sector viewed as crucial in the external liberalization strategy implemented as from the mid-1980s in that country. Lastly, based on methodologies used recently by ECLAC, it will conduct statistical exercises, at the most disaggregated level possible, to evaluate in greater depth the effects of structural change on productivity levels and on the types of heterogeneity present in the sector.

Following this introduction, the rest of the article is organized as follows: section II addresses the topic of structural heterogeneity and the relevance of productive linkages, from the ECLAC structuralist standpoint; section III reviews recent studies that use similar methodologies to analyse productivity trends in Latin America, particularly in Mexican manufacturing industry. Section IV reports the results of the estimations of productivity levels and basic indicators of structural heterogeneity for different levels of aggregation of Mexican manufacturing. Section $\mathrm{V}$ firstly analyses the determinants of productivity trends and evaluates the effects of structural change on the efficiency of the sector's activity classes, branches and divisions through a Fabricant decomposition. It then makes a deeper analysis of some of the characteristics and modes of organization and operation of the "leading" industries in the Mexican specialization pattern. Lastly, section VI sets forth the main conclusions. 


\section{II}

\section{Structural heterogeneity in Latin American thought}

From the 1950s onwards, the framework of theoretical analysis developed by ECLAC highlights two key characteristics that define the "peripheral" status of Latin American economies: (i) their specialization in a few sectors, especially primary and industrial ones with low technological intensity and low income elasticity of demand; and (ii) the existence of major differences in labour productivity compared to the central countries, and between the different "technical layers" that form their productive structure (Rodríguez, 1980). For Aníbal Pinto (1965, 1970 and 1971), who pioneered the concept of heterogeneity, the region's import-substitutionindustrialization strategy made it possible to create a modern non-export sector, with productivity levels above the system average and even similar to those of the export complex. As a result, the fruits of "inward" diversification - the "dual" productive apparatus that was the stereotype for Latin American countries in their early phases of development - became one of structural heterogeneity. This feature is accentuated in the case of higher-level developing economies (Furtado, 1962) in phases characterized by the manufacture of intermediate goods and heavy consumer durables, based on modern technology and greater capital density.

In view of the historical experience of developed countries, Pinto then recommends transferring resources towards the modern sectors, so that technical progress can be disseminated to the rest of the productive apparatus through the "bandwagon effect" of the leading sectors, defined as those with higher productivity levels. Moreover, following the tradition of the models of structural change with unlimited labour supply - such as those of Lewis (1955); Jorgenson (1961), and Fei and Ranis (1961) — Furtado (1963) identifies the need to shift workers from the backward sectors to modern ones as a first step in revitalizing demand. His arguments include the principles of Keynesian analysis, because increasing productivity resulting from a change in the composition of employment justifies wage increases that diversify consumption and in turn make the productive structure more efficient.

To summarize, a productive apparatus of highly varied sectoral productivity, which is poorly integrated and lacks capacity to transmit and diversify technical progress, participates in the international economy under unfavourable terms by exporting products of low value-added. This produces an institutional fabric that is disinclined to accumulate capital and generate technology, resulting in surplus labour and wages that are overwhelmingly at the subsistence level, thereby asymmetrically stratifying the type of consumption and society as a whole (Bielschowsky, 2009).

Based on these premises, the topic of heterogeneity has recently been revived by ECLAC from a standpoint that stresses the importance of the effects of technological change on productive structures. This approach views structural bottlenecks as being reproduced basically because of the widening of the technology gap in relation to the advanced countries (Holland and Porcile, 2005); and the origin of heterogeneity of the productive fabric is studied "in terms of the strategic behaviour of economic agents, identification of the barriers to and determinants of the creation and dissemination of technological capacities" (Cimoli, 2005, p. 6). The analysis therefore stresses the relevance of each productive system's capacity to turn codified knowledge into skills used in firms; and it also extends the study of the relations between productive segments to a complex web of systemic links between enterprises, organizations and the institutional framework (Cimoli and Dosi, 1995).

Although this approach prioritizes the analysis of variables that are specific to the study of technological change, it maintains a key idea in classical development theory, namely that industry is the sector with the greatest bandwagon effects in the economy and includes activities which are naturally capable of assimilating, reproducing and generating technical progress (Prebisch, 1962; Singer, 1950). From this general standpoint, the growing productive duality between modern manufacturing activities (engaged in global dynamics) and other more backward activities (mainly serving a shrinking domestic market in which imports are increasingly important) is a consequence of rapid trade liberalization that calls into question the very essence of the model implemented since the 1980s in Mexico. More specifically, this view considers it essential for Mexican manufacturing structure to become less heterogeneous - both for national productive development and, in general, for a fairer distribution of income. 


\section{III}

\section{Studies of productivity trends in Mexico and Latin America}

To capture and distinguish the importance of the shift of labour between productive sectors and technological change in determining productivity trends in the region, authors associated with ECLAC have developed different approaches to the topic of heterogeneity, using generic techniques based on the shift-share methodology. ${ }^{1}$ ECLAC (2007) finds that the growth of value-added per job averaged $1 \%$ per year over a long time period (19602003), in a sample of nine economies. Nonetheless, the results show major differences between the indicators of the different countries, highlighting the importance of the effect of labour-force recomposition in the total variation of output per employee (structural effect): $70 \%$ of the average change in labour productivity in the region. In fact, in four of the nine countries (Bolivarian Republic of Venezuela, Mexico, Peru, Plurinational State of Bolivia), intrinsic productivity declined relative to technological progress, ${ }^{2}$ "which indicates a move away from the productive frontier" (ECLAC, 2007, p. 32).

In contrast, the ECLAC study also shows that productivity in manufacturing industry grew by $22 \%$ in the period considered, because intrinsic productivity grew by $33 \%$. On this point, the work of Holland and Porcile (2005) confirms that increases in this component are the main determinant of progress in the industry indicator in all countries of the sample (Argentina, Brazil, Chile, Colombia, Mexico and Uruguay). Apart from Mexico, in the 1990s these nations all reported industrial productivity growth rates that were significantly higher than those achieved in previous decades, reflecting the $63.9 \%$ increase in intrinsic productivity, which more than compensated for the decline in the contribution of

\footnotetext{
1 This procedure makes it possible to separate total labour productivity growth in a given period into productivity growth within the activity branches, transfer of labour towards more productive branches (static transfer effect), and the transfer of labour toward more dynamic branches of activity, in other words those displaying the highest productivity growth rates (dynamic transfer effect).

2 ECLAC defines the structural effect as the contribution to productivity growth made by the sectoral recomposition of the labour force; and the intrinsic effect as the variation in labour productivity attributable to changes in the intrinsic productivity of the sectors, in other words variations caused by technological progress (ECLAC, 2007).
}

structural-type effects, driven largely by the privatization, economic-deregulation and trade-liberalization processes being implemented in the region.

Considering the period 1970-2002, the results also confirm employment growth in lower-productivity industrial activities and the scant contribution made by structural change to productive efficiency, thereby increasing heterogeneity in the region's manufacturing complexes. In the specific case of Mexico following its adoption of the "neoliberal" model in the 1980s, labour productivity in the economy as a whole has tended to stagnate. This is shown in the study by Romero (2009) relating to the effects of trade openness, which estimates the average growth of labour productivity economywide in the period $1982-2003$ at $0.5 \%$ per year - far below that recorded in the four previous decades, in which GDP per worker grew rapidly. The calculations presented by ECLAC (2007) confirm this observation: annual productivity growth in Mexico slowed from 3.7\% in the 1960 s to $1.3 \%,-1.8 \%$ and $0.3 \%$, respectively, in the ensuing decades.

With regard to the determinants of these rates in Mexico, the work of Romero reveals the declining trend of the structural effect between 1961 and 2003, which means that the development process in Mexico has not triggered a long-term shift of labour towards dynamic activities. Moreover, the ECLAC document reports the general trend as negative, even though the structural effect is positive as a whole for this period, making it possible to offset a reduction in intrinsic productivity linked to the absence of technical change. Nonetheless, both studies clearly identify a deterioration in the contribution of the structural component to the trend of productivity from the 1980s onwards. In Romero (2009), the structural effect generates annual productivity growth of less than $1 \%$ in the period 1984-2003, with even negative rates in the years between 1992 and 1995. The ECLAC document shows that in the periods 1960-1972 and 1973-1981, the structural effect contributed an annual average of US\$166 and US\$215, respectively, at 2000 prices, to productivity growth measured as value-added per worker, whereas the contribution was no more than US $\$ 77$ under the same constant-price terms in the period 1982-2003. 
The results are even more discouraging at the industry level; Holland and Porcile (2005) estimate a negative contribution for the interaction effect associated with the reallocation of workers to sectors of growing productivity in each of the decades between 1970 and 2000 , and particularly in the 1990s $(-1.26 \%,-3.31 \%$ and $-8.44 \%$, respectively). Meanwhile, ECLAC (2007) reports a contribution of US\$11 per year at 2000 prices, to the growth of labour productivity in Mexican manufacturing throughout the period 1960-2003, as a result of the structural effect as a whole. This figure is in line with the reality of most Latin American countries, as shown by contributions also of US\$11 in Brazil and Costa Rica, and US\$12 in the Bolivarian Republic of Venezuela under the same terms, to give just a few examples. Lastly, Capdevielle confirms: "since the 1970s, the component that determined the increase in manufacturing productivity was its growth within each branch, whereas the change in the composition of production as a result of reallocation and interaction was insignificant" (Capdevielle, 2005, p. 115).

In terms of the trend of the intrinsic component, the figures are somewhat less clear, owing to discrepancies in the methodologies used and, particularly, the different levels of aggregation applied in the exercises. According to ECLAC, unlike what happened in Latin America generally, productivity growth generated by technological change in Mexican manufacturing in the period 1960-2003 was also small, and even less than the contribution of the structural effect (US\$9 at 2000 prices). Nonetheless, the estimations made by Holland and Porcile suggest that the growth of intrinsic productivity in manufacturing (23.78\% on average for the period 1970-2000), while less than the average of the countries in the sample, is greater than the worker-reallocation effect. Lastly, Capdevielle (2005) explains the increase in the indicator as a result of labour reallocation in the years 1988-2003 (67.07 pesos at 1993 prices) in terms of an increase in the efficiency of non-maquila activities which, nonetheless, are not based on technical improvements: "they could have originated from employee-rationalization processes in a context in which trade openness intensified the struggle for local markets" (Capdevielle, 2005, p. 115).

In short, and despite the statistical differences encountered, the few structural studies that exist on productivity trends in Mexican industry reveal the poor performance of the indicator in this sector, and the scant contribution (below the Latin American average) made by both structural change and technological progress to the efficiency of the manufacturing apparatus since the end of the import-substitution-industrialization strategy and, in particular, during the period of the "neoliberal" model. In this sense, the trends observed relate to Mexico's strategy of international productive engagement, consisting of specialization in certain activity branches and specific segments of production within selected "leading" industries, by exploiting low-skilled labour. This strategy is in fact compatible with the interests of the large transnational groups that relocate segments of the productive process to reduce costs (particularly labour costs) and thus increase efficiency and consolidate their global manufacturing networks (Gereffi, 1995).

\section{IV \\ Trend of structural heterogeneity by activity classes in Mexican manufacturing in the period 1994-2008}

In the framework of the polarization of Mexico's manufacturing structure and the deepening and apparent extension of heterogeneity to the within-sector level, a study with some degree of precision on the trend of productivity differentials in the sector would require statistical treatment at the most disaggregated level possible (non-existent today to owing to the lack of long and consistent official data series). To satisfy this requirement and analyse the within-sector heterogeneity highlighted by certain authors, a database was created which estimates monthly labour productivity, at constant December 2003 prices, for each of the years in the period 1994-2008, with respect to 200 classes of Mexican manufacturing activity. This exercise was based on the Monthly Manufacturing Survey (EIM) in the Mexican Activities and Products Classification 
(CMAP) produced by the National Institute of Statistics and Geography (INEGI). ${ }^{3}$ Fine-tuning the analysis, two equal subperiods were defined (1994-2001 and 20012008) to facilitate comparisons and take account of the widely acknowledged fact that the economic liberalization strategy fuelled employment growth in the first few years of its application in the country.

In general terms, the results show that during the periods 1994-2001 and 2001-2008, productivity levels in the Mexican manufacturing sector grew at moderate annual rates of $2.3 \%$ and $2.6 \%$, respectively (see table 1 ). The tendency for these levels to stagnate in a context

3 After adding together the monthly values, the annual figures are deflated at 2003 prices, using the national producer price index for the manufacturing sector, published by Banco de México (BANXICO). The indicator is then estimated by calculating the quotient between total gross production and man-hours worked for the different activity groups. The productivity indicator cannot be calculated for five activity classes (321111, 382301, 383202, 384204, 385006) out of the 205 covered by the survey, because data on the value of output or man-hours worked in those activities are not available for the period 2003-2008. of continuous technological change clearly reveals the failure to generate positive externalities in the national manufacturing fabric and the lack of an adequate institutional productive infrastructure to increase the specific returns to each activity.

In the case of Mexico, there are also marked differences in the trend of the indicator both between different divisions, branches and classes of activity, and between the periods considered. In the first subperiod (1994-2001), activity branches involved in pharmaceutical manufacturing, the automotive industry, and cement, lime and gypsum factories (the latter associated with construction activity) posted productivity growth in excess of 5.5\% per year; whereas the more traditional divisions, such as textiles and wood, as a whole reported reductions in their output-labour ratios (see table 1). The subperiod 2001-2008 is characterized by a stagnation of productivity levels in manufacturing generally, against a backdrop of recurrent episodes of contracting international markets. This is alarming since, historically, productivity has failed to grow in a very few periods only.

\begin{tabular}{|c|c|c|c|c|c|}
\hline \multirow{2}{*}{ Division/branch } & \multicolumn{3}{|c|}{ Output per man-hour worked } & \multicolumn{2}{|c|}{ Annual growth rate } \\
\hline & 1994 & 2001 & 2008 & 1994-2001 & 2001-2008 \\
\hline I Food, beverages and tobacco & 465.9 & 489.2 & 535.8 & 0.7 & 1.3 \\
\hline Branch 3112 Dairy product manufacturing & 656.9 & 726.7 & 689.6 & 1.5 & -0.7 \\
\hline Branch 3130 Beverage manufacturing & 396.1 & 457.4 & 565.8 & 2.1 & 3.1 \\
\hline II Textile, apparel and leather manufacturing & 197.0 & 168.8 & 187.2 & -2.2 & 1.5 \\
\hline III Wood industry and wood product manufacturing & 187.9 & 173.3 & 176.7 & -1.1 & 0.3 \\
\hline IV Paper and paper product manufacturing, printing and publishing & 360.8 & 372.7 & 365.8 & 0.5 & -0.3 \\
\hline V Chemical, petroleum product, rubber and plastic product manufacturing & 496.0 & 577.4 & 686.4 & 2.2 & 2.5 \\
\hline Branch 3512 Basic chemical manufacturing & 831.1 & 909.9 & 1584.3 & 1.3 & 8.2 \\
\hline Branch 3521 Pharmaceutical-pharmochemical industry & 568.0 & 826.0 & 760.4 & 5.5 & -1.2 \\
\hline Branch 3522 Other chemical and chemical product manufacturing & 606.5 & 707.3 & 741.2 & 2.2 & 0.7 \\
\hline $\begin{array}{l}\text { VI Nonmetallic mineral product manufacturing except petroleum products } \\
\text { and coal }\end{array}$ & 406.2 & 455.5 & 479.5 & 1.6 & 0.7 \\
\hline $\begin{array}{l}\text { Branch } 3691 \text { Cement, lime, gypsum and other non-metallic mineral product } \\
\text { manufacturing }\end{array}$ & 538.4 & 812.5 & 785.5 & 6.1 & -0.5 \\
\hline VII Basic metal manufacturing & 836.9 & 934.4 & 1942.7 & 1.6 & 11.0 \\
\hline Branch 3710 Basic iron and steel manufacturing & 844.2 & 1043.6 & 2149.0 & 3.1 & 10.9 \\
\hline Branch 3720 Basic non-ferrous metal manufacturing & 822.8 & 746.0 & 1559.6 & -1.4 & 11.1 \\
\hline VIII Metal product, machinery and equipment manufacturing & 519.4 & 711.4 & 755.3 & 4.6 & 0.9 \\
\hline Branch 3841 Automotive industry & 895.0 & 1314.3 & 1377.6 & 5.6 & 0.7 \\
\hline IX Other manufacturing industries & 189.3 & 174.7 & 189.6 & -1.1 & 1.2 \\
\hline Total manufacturing & 446.1 & 523.4 & 625.0 & 2.3 & 2.6 \\
\hline
\end{tabular}

Source: prepared by the author on the basis of National Institute of Statistics and Geography (INEG), "Encuesta industrial mensual (CMAP), 205 clases de actividad económica", 2011 [online] http://dgcnesyp.inegi.org.mx/cgi-win/bdieintsi.exe/NIVZ101290009000020002\#ARBOL 
In addition, between 2001 and 2008, the indicator displays high growth rates of above $10 \%$ in the two branches of basic metal manufacturing, and an $8.2 \%$ increase in the manufacture of basic chemicals (see table 1). Nonetheless, it needs to be stated, firstly, that the variations observed in productivity levels could be biased by the unequal trend of prices in the different manufacturing activities. Consequently, some industries could display productivity increases that are not related either to the adoption of processes, innovative machinery or both, or to greater investment in resources. On this point, the high growth rates of the output-labour ratio in the branches of basic metal manufacturing since 2001 largely reflects substantial increases in the value of the goods manufactured. In fact, the national producer price index (INPP) of division VII, corresponding to basic metal manufacturing, records an increase of $202.7 \%$ for the period 2002-2008, while the general index for total manufacturing rose by $56.3 \%$ in those years. ${ }^{4}$

Although, as noted by Romero (2009), the absolute values of the output-labour ratio vary according to each activity's specific capital-labour ratio, the gap between traditional industries and those with greater participation in the global arena has expanded as a result of trade liberalization. For example, whereas in 1994, productivity in the automotive industry was 4.5 and 4.8 times that recorded by the textile and wood manufacturing divisions, respectively, by 2008 these coefficients were 7.4 and 7.8 times. ${ }^{5}$ It should be noted that in this case, the price

4 Calculated on the basis of Banco de México (BANXICO, 2011).

5 Calculated on the basis of the figures shown in table 1. effect could be considered residual, because in the three groups, the increase in the INPP is less than for the sector as a whole. From January 1994 to December 2008, the value of goods produced by the automobile and truck assembly branch grew by $235.4 \%$, that of textile products by $197.5 \%$ and that of wood products by $204.1 \%$, whereas the figure for manufacturing as a whole was $261.9 \% .{ }^{6}$

On this point, traditional statistical indicators of dispersion reveal the increasing structural heterogeneity of the Mexican manufacturing sector, both horizontal - between the elements of the different aggregation levels — and vertical — within activity groups, whether divisions or branches (intra-sectoral heterogeneity). As shown in table 2, both the standard deviation and the coefficient of variation are higher at higher levels of disaggregation, which confirms the relevance of analysing horizontal heterogeneity by activity classes. Similarly, the trend of both indicators for the different samples broadly shows that after two short periods, 1994-1996 (rising) followed by 1997-1999 (falling), there is a clear and sustained trend for productivity gaps to widen across the sector from 2000 onwards, as shown in figure 1 in the case of the standard deviation.

In particular, it is worth noting the increase in the coefficient of variation and the standard deviation of productivity at the division level from 2001 to 2008 (59\% and $108.4 \%$, respectively). In fact, whereas in 2008 output per man-hour worked was less than 190 pesos at 2003 prices in three of the nine divisions, basic metal manufacturing posted an increase of 1,942.7 pesos (see

6 See BANXICO (2011).

TABLE 2

Indicators of the dispersion of labour productivity in the manufacturing sector at different levels of aggregation, 1994-2008

(Pesos per man-hour worked, at December 2003 prices, and percentages)

\begin{tabular}{|c|c|c|c|c|c|c|c|c|c|c|}
\hline \multirow{2}{*}{$\begin{array}{l}\text { Years/period } \\
\text { Dispersion/aggregation }\end{array}$} & \multicolumn{2}{|c|}{1994} & \multicolumn{2}{|c|}{2001} & \multicolumn{2}{|c|}{2008} & \multicolumn{2}{|c|}{$\begin{array}{c}\text { Growth rate } \\
1994-2008\end{array}$} & \multicolumn{2}{|c|}{$\begin{array}{l}\text { Growth rate } \\
2001-2008\end{array}$} \\
\hline & $\mathrm{CV}$ & SD & $\mathrm{CV}$ & SD & $\mathrm{CV}$ & SD & $\mathrm{CV}$ & SD & $\mathrm{CV}$ & SD \\
\hline Divisions & 51.5 & 209.3 & 58.6 & 264.2 & 93.2 & 550.6 & 90.0 & 163.1 & 59.0 & 108.4 \\
\hline Branches & 69.1 & 304.1 & 79.1 & 373.6 & 89.7 & 520.1 & 29.8 & 71.0 & 13.4 & 39.2 \\
\hline Activity classes & 85.5 & 371.8 & 93.9 & 427.1 & 112.9 & 621.7 & 32.0 & 67.2 & 20.2 & 45.6 \\
\hline
\end{tabular}

Source: prepared by the author on the basis of National Institute of Statistics and Geography (INEG), "Encuesta industrial mensual (CMAP), 205 clases de actividad económica”, 2011 [online] http://dgcnesyp.inegi.org.mx/cgi-win/bdieintsi.exe/NIVZ101290009000020002\#ARBOL.

$\mathrm{CV}$ : Coefficient of variation.

SD : Standard deviation. 
FIGURE 1

Standard deviation of productivity at different levels of aggregation, 1994-2008

(Pesos per man-hour worked, at December 2003 prices)

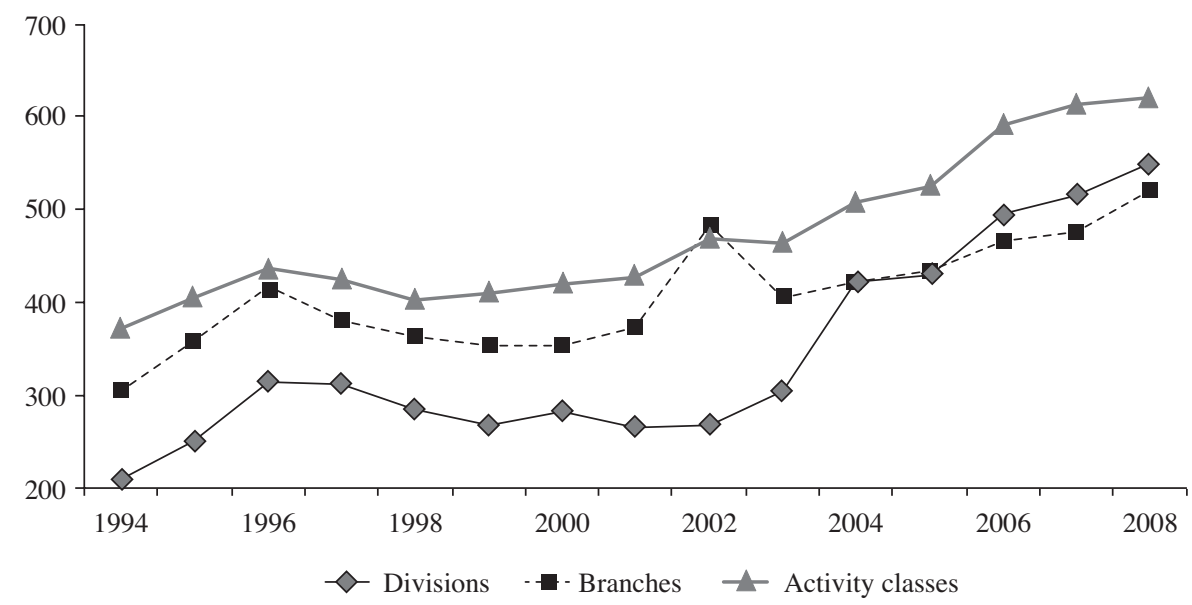

Source: prepared by the author on the basis of National Institute of Statistics and Geography (INEG), "Encuesta industrial mensual (CMAP), 205 clases de actividad económica", 2011 [online] http://dgcnesyp.inegi.org.mx/cgi-win/bdieintsi.exe/NIVZ101290009000020002\#ARBOL .

table 1). At the most detailed level possible, the analysis for the 200 activity classes shows that the standard deviation increased by $67.2 \%$ in the period 1994-2008, with a $45.6 \%$ rise between 2001 and 2008 (see table $2)$. In this latter subperiod (2001-2008) the process of expanding heterogeneity occurs alongside a general stalling of productivity, reflecting the progressive isolation of competitive activities associated with global operations.

In this regard, the results obtained are consistent with the findings of Holland and Porcile (2005), who show that Mexico experienced a process of sigma divergence between industrial sectors in the 1990s. In their estimations, the coefficient of variation calculated on the basis of productivity in just 28 sectors, increased by $35.6 \%$ from 1990 to 1999, and the Gini coefficient for that sample rose from 0.25 to 0.29 in the same period. The exercise performed here also makes it possible to complement and extend the analysis of these authors, in that during the first decade of the millennium, the response of labour productivity remained weak, and the increasing dispersion trend was not reversed; on the contrary it seems to have worsened as a result of a growth pattern which Holland and Porcile describe as one of low capacity to absorb underemployment and unemployment.

With regard to within-sector heterogeneity, the estimated productivity indicators of the activity classes within each division show that the gap-widening process was slower than that which occurred between sectors in the period 1994-2008, as suggested by the fact that the growth rates of the dispersion indicators are generally lower. There are also marked differences in the trend both of the standard deviation and of the coefficient of variation between the sectors considered. Whereas in the "Paper and paper product manufacturing, printing and publishing" division, these variations were in fact negative $(-6.8 \%$ and $-0.5 \%$, respectively), in "Basic metal manufacturing" the standard deviation increased by $296.9 \%$ (see table 3 ).

Although the number of activity classes in each division could bias these results, making the indicators unstable - particularly in sectors with a small number of activities, such as basic metal manufacturing - the evidence is clear for the period 1984-2008 that there are manufacturing groupings in which intra-sectoral heterogeneity grew moderately or even declined (food products, beverages and tobacco; textiles, apparel and the leather industry; paper and paper product manufacturing, printing and publishing), and others where there was considerable growth (wood industry and wood products; chemicals, petroleum products, rubber and plastic products; nonmetallic mineral products, except petroleum products and coal; basic metal manufacturing; and metal products, machinery and equipment).

The differences in the rate of increase of the two types of heterogeneity defined above can be explained by interpreting the intra-sectoral phenomenon as a 
result of the intensification of a process in which the local productive apparatus is becoming less interlinked, owing to the way Mexican manufacturing participates in the global economy. From this standpoint, increasing productive duality is generally revealed between sectors as a result of an exclusive specialization process, explained by the change in the economic model and, more specifically, within each of the sectors as a result of the subsequent extension of the maquila process in more complex forms.

TABLE 3

Indicators of the dispersion of labour productivity across activity classes

in each manufacturing division, 1994-2008

(Pesos per man-hour worked, at December 2003 prices, and percentages)

\begin{tabular}{|c|c|c|c|c|c|c|c|c|}
\hline \multirow{2}{*}{$\begin{array}{l}\text { Years/ period } \\
\text { Dispersion/division }\end{array}$} & \multicolumn{2}{|c|}{1994} & \multicolumn{2}{|c|}{2001} & \multicolumn{2}{|c|}{2008} & \multicolumn{2}{|c|}{$\begin{array}{l}\text { Growth rate } \\
1994-2008\end{array}$} \\
\hline & $\mathrm{CV}$ & SD & $\mathrm{CV}$ & SD & $\mathrm{CV}$ & SD & $\mathrm{CV}$ & SD \\
\hline Food, beverages and tobacco ( 38 classes) & 72.8 & 514.3 & 70.1 & 499.6 & 80.2 & 615.2 & 10.2 & 19.6 \\
\hline $\begin{array}{l}\text { Textile, apparel and leather manufacturing } \\
\text { (31 classes) }\end{array}$ & 61.0 & 128.4 & 76.4 & 138.8 & 72.0 & 133.8 & 18.0 & 4.2 \\
\hline $\begin{array}{l}\text { Wood industry and wood product manufacturing } \\
\text { ( } 5 \text { classes })\end{array}$ & 31.6 & 59.8 & 38.6 & 71.4 & 54.3 & 104.7 & 72.2 & 75.1 \\
\hline $\begin{array}{l}\text { Paper and paper product manufacturing, printing } \\
\text { and publishing ( } 9 \text { classes) }\end{array}$ & 42.2 & 154.4 & 39.9 & 147.9 & 42.0 & 143.9 & -0.5 & -6.8 \\
\hline $\begin{array}{l}\text { Chemical, petroleum product, rubber and plastic } \\
\text { product manufacturing ( } 38 \text { classes) }\end{array}$ & 65.2 & 343.6 & 63.3 & 364.3 & 85.5 & 636.6 & 31.0 & 85.3 \\
\hline $\begin{array}{l}\text { Nonmetallic mineral product manufacturing except } \\
\text { petroleum products and coal ( } 16 \text { classes) }\end{array}$ & 88.4 & 279.8 & 126.4 & 460.3 & 115.8 & 437.2 & 30.9 & 56.3 \\
\hline Basic metal manufacturing ( 7 classes) & 53.2 & 378.6 & 60.8 & 503.5 & 83.4 & 1502.8 & 56.7 & 296.9 \\
\hline $\begin{array}{l}\text { Metal product, machinery and equipment } \\
\text { manufacturing ( } 53 \text { classes) }\end{array}$ & 80.6 & 286.3 & 110.6 & 419.6 & 97.1 & 435.8 & 20.5 & 52.2 \\
\hline Other manufacturing industries ( 3 classes) & 27.8 & 44.8 & 38.3 & 54.5 & 40.5 & 60.5 & 45.7 & 35.1 \\
\hline Total manufacturing industry & 85.5 & 371.8 & 93.9 & 427.1 & 112.9 & 621.7 & 32.0 & 67.2 \\
\hline
\end{tabular}

Source: prepared by the author on the basis of National Institute of Statistics and Geography (INEG), "Encuesta industrial mensual (CMAP), 205 classes de actividad económica", 2011 [online] http://dgcnesyp.inegi.org.mx/cgi-win/bdieintsi.exe/NIVZ101290009000020002\#ARBOL.

$\mathrm{CV}$ : Coefficient of variation.

SD : Standard deviation.

\section{V \\ Mexican manufacturing: analysis of the determinants of productivity and structural heterogeneity}

Based on the methodology used by previous studies on the issue discussed at the start of this article, this section uses the productivity indicators constructed for the 200 activity classes of Mexican manufacturing for the period 1994-2008, for the purpose of evaluating the contributions made by technological progress and structural change to the trends observed in productivity and in the sector's structural heterogeneity. Using a shift-share-type statistical technique (Maddison, 1952; ECLAC, 2007), variations in productivity levels are separated into two predefined effects (intrinsic and structural), for different levels of aggregation (division, branch and activity class) and periods of analysis. 
In the generic breakdown known as the Fabricant formula, the importance of each factor (technological progress and structural change) is weighted by the coefficients $\mathrm{S}_{\mathrm{i}}{ }^{\mathrm{t}}$ and $\mathrm{P}_{\mathrm{i}}{ }^{0}$, as shown below:

$$
\begin{aligned}
& \left(P^{T}-P^{0}\right)=\left[\left(P_{1}^{T}-P_{1}^{o}\right) \cdot S_{1}^{T}+\left(P_{2}^{T}-P_{2}^{o}\right) \cdot S_{2}^{T}\right]+ \\
& {\left[\left(S_{1}^{T}-S_{1}^{o}\right) \cdot P_{1}^{o}+\left(S_{2}^{T}-S_{2}^{o}\right) \cdot P_{2}^{o}\right]}
\end{aligned}
$$

After changing the time-base of the weighting and generalizing the formula for $n$ sectors, ECLAC (2007) obtains the following breakdown of the differential between two aggregate levels of productivity at two points in time:

$$
\begin{aligned}
& \left(P^{T}-P^{0}\right)=\sum_{i=1}^{n}\left[\left(P_{i}^{T}-P_{i}^{0}\right),\left(S_{i}^{0}-S_{i}^{T}\right) / 2\right]+ \\
& \sum_{i=1}^{n}\left[\left(S_{i}^{T}-S_{l}^{0}\right) \cdot\left(P_{i}^{0}-P_{i}^{T}\right) / 2\right]
\end{aligned}
$$

where $\mathrm{P}_{\mathrm{i}} \mathrm{t}^{\mathrm{i}}$ is productivity in sector $\mathrm{i}(\mathrm{i}=1,2, \ldots \mathrm{n})$ at time $\mathrm{t}=0, \mathrm{~T}$ and $\mathrm{S}_{\mathrm{i}} \mathrm{t}$ is the share of sector $\mathrm{i}(\mathrm{i}=1,2, \ldots \mathrm{n})$ in the total active employed population at $\mathrm{t}=0, \mathrm{~T}$. The first term on the right-hand side of the equation represents the variation in labour productivity attributable to changes in the intrinsic productivity of the $n$ sectors. The second term indicates the contribution made by the sectoral recomposition of the labour force. If employment grows by more in sectors of high intrinsic productivity, the net effect will be positive; on the contrary, if the net recipients of labour are low-productivity sectors, then the final result of the factor recomposition will be negative (ECLAC, 2007, p. 28).

In the reformulation shown below, the estimation is performed for the years 1994 and 2008, for the 200 classes of manufacturing activity, so the share of each activity class, both in employment and in the trend of productivity, is measured in relation to the total manufacturing sector. For example:

$$
\begin{aligned}
& \left(P^{08}-P^{94}\right)=\sum_{i=1}^{n}\left[\left(P_{i}^{08}-P_{i}^{94}\right) \cdot\left(S_{i}^{94}+S_{i}^{08}\right) / 2\right]+ \\
& \sum_{i=1}^{n}\left[\left(S_{i}^{08}-S_{l}^{94}\right) \cdot\left(P_{i}^{94}+P_{i}^{08}\right) / 2\right]
\end{aligned}
$$

In this breakdown, the weightings depend on the average of the two randomly chosen reference years, so the results vary according to the degree of disaggregation being used; in other words, while in all cases the sum of the intrinsic and structural effects gives the same total productivity change between the two years considered, in contrast, the sum of each of the concepts does not give the same results if 200 activity classes, 50 branches or nine divisions are considered. Although the differences are not considerable and in no way alter the conclusions of the analysis, to avoid statistical discrepancies the results of the exercise presented for each branch and division are obtained by summing the values of the classes they encompass.

As shown in table 4, the findings firstly confirm what was noted above: the increase in productivity for manufacturing as a whole in the period studied (178.94 pesos at 2003 prices, or $2.4 \%$ as an annual average), and particularly in its first subperiod from 1994 to 2001 ( 77.27 pesos and $2.3 \%$, respectively), should be considered small, compared to the $2.7 \%$ annual growth rate of that indicator between 1970 and 1990 (ECLAC, 2007 p. 62). Secondly, structural change makes virtually no contribution to the increase in the indicator; in other words, the shift of workers from low-productivity activity classes to other more efficient ones explains only $6.2 \%$ of the increase in output per man-hour worked over the period 1994-2008. One plausible hypothesis, which goes beyond the scope of this study, is that despite the changes that have taken place in manufacturing industry, there was no structural change in the sector. In contrast, the intrinsic effect, in other words productivity increases within each activity class owing to productive reorganization or technical progress, explains $93.8 \%$ of the growth of output per man-hour worked in manufacturing between 1994 and 2008, and 95.2\% of its growth between 2001 and 2008.

TABLE 4

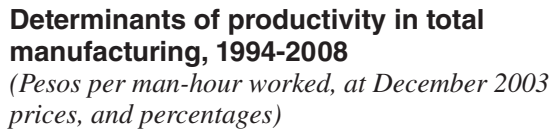

\begin{tabular}{lrrr}
\hline Effects/period & Intrinsic & Structural & \multicolumn{1}{c}{ Total } \\
\hline $1994-2001$ & 66.37 & 10.90 & 77.27 \\
$2001-2008$ & 96.75 & 4.92 & 101.67 \\
$1994-2008$ & 167.91 & 11.02 & 178.94 \\
\hline
\end{tabular}

Source: prepared by the author on the basis of National Institute of Statistics and Geography (INEG), "Encuesta industrial mensual (CMAP), 205 classes de actividad económica", 2011 [online] http://dgcnesyp.inegi. org.mx/cgi-win/bdieintsi.exe/NIVZ101290009000020002\#ARBOL. 
The estimations obtained also show that efficient practices are heavily concentrated in the manufacturing structure, and increasingly so, irrespective of the aggregation levels of the analysis. At the large-division level, while three divisions make negative contributions to the sector's productivity trend, another two hardly contribute at all, while the four remaining divisions account for $102.7 \%$ of the total effect on the indicator and $99 \%$ of the intrinsic effect in the subperiod 1994-2008. Similarly, at the branch level, just two of the 50 existing branches (motor vehicle manufacturing and the basic iron and steel industry) jointly account for $52 \%$ of productivity increase in Mexican manufacturing and $47.9 \%$ of the sector's total intrinsic effect in that period (see table 5).

TABLE 5

Determinants of labour productivity in the divisions and selected branches
of the manufacturing sector, 1994-2008
(Pesos per man-hour worked, at December 2003 prices, and percentages)

\begin{tabular}{|c|c|c|c|}
\hline Division/branch & $\begin{array}{c}\text { Intrinsic } \\
\text { effect }\end{array}$ & $\begin{array}{c}\text { Structural } \\
\text { effect }\end{array}$ & Total effect \\
\hline I Food, beverages and tobacco & 28.50 & 9.49 & 37.99 \\
\hline Branch 3112 Dairy product manufacturing & 2.65 & 5.87 & 8.51 \\
\hline Branch 3130 Beverage manufacturing & 14.78 & -4.66 & 10.12 \\
\hline II Textile, apparel and leather manufacturing & -3.35 & -4.61 & -7.96 \\
\hline III Wood industry and wood product manufacturing & -0.31 & -0.86 & -1.17 \\
\hline IV Paper and paper product manufacturing, printing and publishing & -0.42 & 1.93 & 1.50 \\
\hline V Chemical, petroleum product, rubber and plastic product manufacturing & 30.95 & -2.70 & 28.25 \\
\hline Branch 3512 Basic chemical manufacturing & 14.13 & -4.94 & 9.19 \\
\hline Branch 3521 Pharmaceutical-pharmochemical industry & 5.69 & 6.19 & 11.87 \\
\hline Branch 3522 Other chemical and chemical product manufacturing & 4.62 & 0.93 & 5.55 \\
\hline VI Nonmetallic mineral product manufacturing except petroleum products and coal & 5.84 & -2.89 & 2.95 \\
\hline Branch 3691 Cement, lime, gypsum and other non-metallic mineral product manufacturing & 5.71 & -4.17 & 1.54 \\
\hline VII Basic metal manufacturing & 50.02 & 6.66 & 56.68 \\
\hline Branch 3710 Basic iron and steel manufacturing & 37.03 & 5.58 & 42.61 \\
\hline Branch 3720 Basic non-ferrous metal manufacturing & 12.99 & 1.08 & 14.07 \\
\hline VIII Metal product, machinery and equipment manufacturing & 56.74 & 4.17 & 60.91 \\
\hline Branch 3841 Automotive industry & 43.44 & 7.01 & 50.45 \\
\hline IX Other manufacturing industries & -0.05 & -0.16 & -0.21 \\
\hline Total manufacturing & 167.91 & 11.02 & 178.94 \\
\hline
\end{tabular}

Source: prepared by the author on the basis of National Institute of Statistics and Geography (INEG), "Encuesta industrial mensual (CMAP), 205 classes de actividad económica", 2011 [online] http://dgcnesyp.inegi.org.mx/cgi-win/bdieintsi.exe/NIVZ101290009000020002\#ARBOL.

It is particularly significant that the branches that contribute most to the productivity increase per manhour worked in manufacturing are also those with the highest levels of manufacturing in the structure. In fact, the eight branches with the highest output values in the sector in 2008 are also among the top nine contributors to labour productivity between 1994 and 2008. In brief, efficiency gains occur exclusively in the productive fabric's specialization hubs, and they generally involve large firms participating in global dynamics that are able to achieve economies of scale, thereby confirming the scant dissemination of technical progress in the structure or positive spillovers from the leading industries to the rest of the sector.
Several studies have documented these limited technological spillovers in Mexican manufacturing at the sector level; Arroyo and Cárcamo (2010) note the introduction of innovations and training, but also the persistence of a large majority of small and mediumsized enterprises (SMEs) using low technology, low-skill labour, and minimal design and management skills, in the post-trade-liberalization textile industry. Castañón, Solleiro and Del Valle (2003) make a compilation of the best technologies in several branches of the food sector, characterized by groups undergoing permanent modernization processes. Nonetheless, they stress the role of these changes as entry barriers for SMEs, and the consequent breakdown of local value chains owing to 
the failure to disseminate these advances in agriculture. Lastly, Álvarez (2002) highlights the fact that changes in the motor-vehicle industry, one of the most dynamic in Mexico's manufacturing sector, have left little room for domestic parts manufacturers to enter the productive chain, while at the same time encouraging new foreign firms to enter the domestic market.

As shown in figure 2, these claims are confirmed by the analysis at the most disaggregated level possible, because 10 of the 200 activity classes considered, or just $5 \%$ of the sample, contribute $72.3 \%$ of the growth in labour productivity in manufacturing, and $63.4 \%$ of productivity increases recorded in the indicator as a result of efficiency improvements within each of the classes in the subperiod 1994-2008. The concentration is even greater in the subperiod 1994-2001, where the total effect of the 10 classes that contribute most to the indicator exceeds that of manufacturing as a whole. This means that the 190 remaining activities record a net decrease in labour productivity and, consequently, a negative overall effect in those years. Thus $95 \%$ of the manufacturing sector as a whole made no productivity progress during the seven years following the entry into force of the North American Free Trade Agreement (NAFTA) in 1994).

Lastly, there are several key characteristics of the activity classes in which productivity increases are concentrated in the period studied (1994-2008) and which are also the activities with the largest weight in the sector's total output in $2008,{ }^{7}$ in other words, the industries that we could be identified as "leaders" of the current manufacturing specialization model. The first of these display low levels both in terms of the value-added percentage contained in the products of these classes, particularly considering the high level of plant modernization, and also in the extent to which they are integrated into the domestic productive fabric.

In fact, when one attempts to classify these leading activities by type, it turns out that only the beverage industry (brewing and soft drinks manufacturing) in 2008 reports linkage coefficients and value-added in production that are above the overall manufacturingsector average. ${ }^{8}$ Moreover, when these classes are plotted in a chart in which the axes measure these coefficients and the total sector data are at the origin, it is found that two of the six considered ("Automobile and truck manufacturing and assembly", and "Smelting, pressing, refining and extrusion of nonferrous metals") are in the bottom left quadrant, in other words, with a linkage coefficient and share of value-added in production below the manufacturing-sector average (see figure 3).

\footnotetext{
7 The seven highest-output activity classes in the manufacturing sector in 2008 accounted for $36.5 \%$ of total manufacturing output in that year. Significantly, except for brewery activity, they are also those that report the largest increases in labour productivity during the period 1994-2008.

8 Production is divided into two components: intermediate consumption and value-added, with data generated directly by INEGI. This study considers the share of value-added in production.
}

FIGURE 2

Determinants of productivity in total manufacturing and in 10 selected classes, 1994-2008 (Pesos per man-hour worked, at December 2003 prices, and percentages)

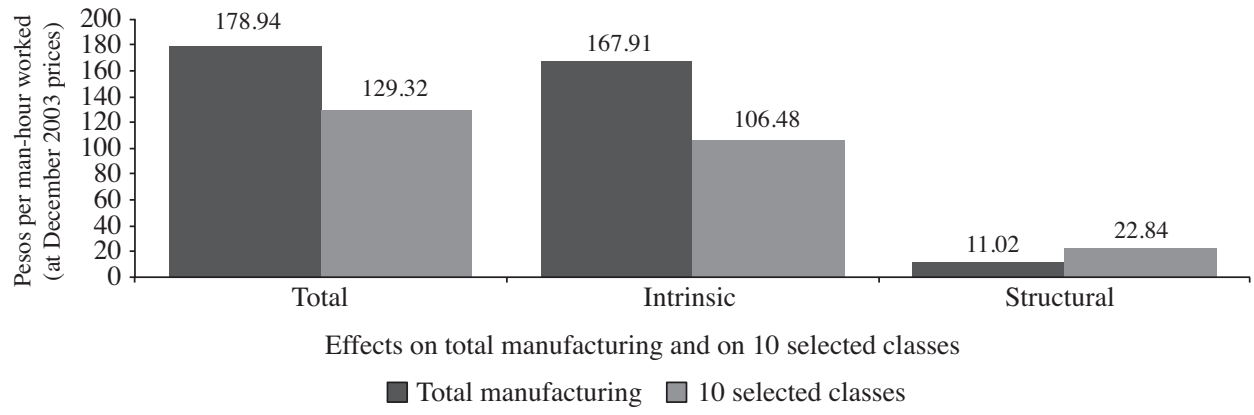

Source: prepared by the author on the basis of National Institute of Statistics and Geography (INEG), "Encuesta industrial mensual (CMAP), 205 classes de actividad económica”, 2011 [online] http://dgcnesyp.inegi.org.mx/cgi-win/bdieintsi.exe/NIVZ101290009000020002\#ARBOL. 


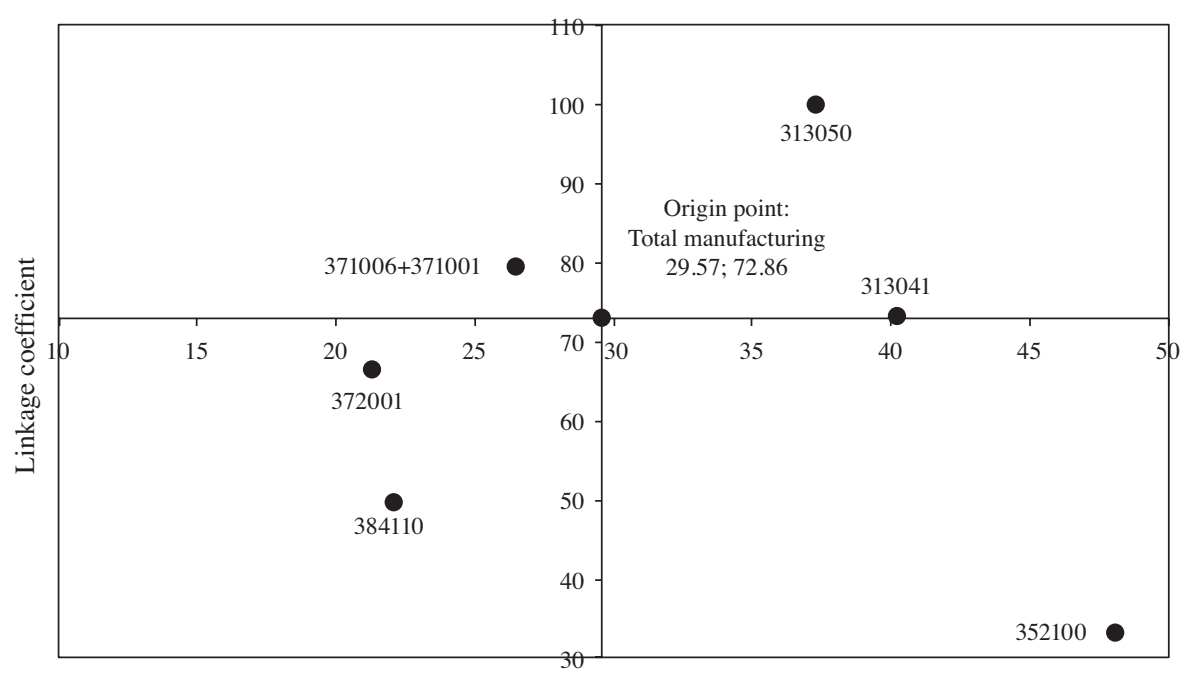

Value added/output

Source: prepared by the author on the basis of National Institute of Statistics and Geography (INEG), "Encuesta industrial mensual (CMAP), 205 classes de actividad económica", 2011 [online] http://dgcnesyp.inegi.org.mx/cgi-win/bdieintsi.exe/NIVZ101290009000020002\#ARBOL.

a The linkage coefficient is calculated as the fraction of the value of national raw materials and auxiliary inputs consumed in the total value of raw materials and auxiliary inputs consumed in production. This is an approximation to the share of local inputs in total inputs consumed in the productive process.

b To make the analysis consistent and use data obtained from sources under the North American Industry Classification System (NAICS), based on the activity classes of the CMAP classification, the following equivalences were defined: 384110 (Motor vehicle and truck manufacturing) corresponds to branch 3361 of the NAICs; 371001+371006 (Smelting and primary pressing of iron and steel and manufacture of steel sheets and other steel products) corresponds to Branch 3311; 372001 (Smelting, pressing, refining and extrusion of nonferrous metals) corresponds to activity class $331419 ; 352100$ (Manufacture of pharmaceutical products) corresponds to Branch 3254; 313050 (Manufacture of soft drinks and other non-alcoholic drinks) corresponds to activity 312111; and 313041 (Production of beer) corresponds to activity class 312120.

The graphical representation also suggests that these activities engage with the wider domestic economy in different ways. The soft drink and other non-alcoholic beverage industry is highly integrated into the national economy, because it sells $99.6 \%$ of its products on the Mexican market, its share of value added in output is greater than the sector average, and it displays the highest linkage coefficient of the 200 classes of activity present in the database. At the other extreme, automobile and truck manufacture and assembly sector, which is fully engaged in international value chains, displays very low levels in all of these indicators. Among other factors, this reflects poor linkages with local suppliers and sales that are biased towards the global market.

Lastly, the data show the negligible weight of investment in the "dynamic" industries of Mexican manufacturing in 2008. For example, automobile and truck manufacturing and assembly invested just $5.8 \%$ of the value-added generated, whereas in none of the activity classes of the basic metal manufacturing considered is the percentage as high as $2.5 \%$. Nonetheless, the two classes with the highest investment coefficients (pharmaceutical product manufacturing and breweries), are also the industries with the largest share of value added in output. A notable case is the pharmaceutical industry, controlled by large TNCs, which records the highest share of value-added in production among the sector's leading activity classes. This industry makes its products essentially for the domestic market $(88.5 \%$ of its total sales), but uses mostly imported raw materials and inputs in its production processes, which means a low linkage coefficient: $33 \%$ (see table 6). 


\begin{tabular}{|c|c|c|c|c|}
\hline Activity Classes & $\begin{array}{l}\text { Value added/ } \\
\text { production }\end{array}$ & $\begin{array}{l}\text { Linkage } \\
\text { coefficient }\end{array}$ & $\begin{array}{l}\text { Share of national } \\
\text { sales in total }\end{array}$ & $\begin{array}{l}\text { Investment/ } \\
\text { Value added }\end{array}$ \\
\hline Motor vehicle and truck manufacturing and assembly & 22.08 & 49.67 & 18.88 & 5.76 \\
\hline $\begin{array}{l}\text { Smelting and primary pressing of iron and steel }+ \\
\text { manufacture of steel sheets and other steel products }\end{array}$ & 26.48 & 79.37 & 72.93 & 0.22 \\
\hline $\begin{array}{l}\text { Smelting, pressing, refining and extrusion of } \\
\text { nonferrous metals }\end{array}$ & 21.29 & 66.55 & 25.71 & 2.41 \\
\hline Pharmaceutical product manufacturing & 48.11 & 33.01 & 88.54 & 6.31 \\
\hline $\begin{array}{l}\text { Soft drink and other non-alcoholic beverage } \\
\text { manufacturing }\end{array}$ & 37.31 & 99.99 & 99.58 & 3.99 \\
\hline Brewing & 40.20 & 73.10 & 67.87 & 15.30 \\
\hline Total manufacturing & 29.57 & 72.86 & 74.50 & 5.97 \\
\hline
\end{tabular}

Source: prepared by the author on the basis of National Institute of Statistics and Geography (INEG), "Encuesta industrial mensual (CMAP), 205 classes de actividad económica”, 2011 [online] http://dgcnesyp.inegi.org.mx/cgi-win/bdieintsi.exe/NIVZ101290009000020002\#ARBOL.

Structural heterogeneity in Mexican manufacturing is also seen in the different modes of operation and business organization in the sector's dynamic activities, as a result of the wide range of expansion strategies deployed by GVCs worldwide (Gereffi, 1994; Gereffi, Humphrey and Sturgeon, 2005; Kaplinsky, 2000). This heterogeneity of dynamic activities and their trend

\section{VI}

\section{Conclusions}

In the tradition of Latin American thought, the pioneers of the concept of structural heterogeneity argued that the modernization of poorly integrated structures, which were technologically dependent on the exterior and unable to transmit and diversify technological progress, could foster imbalances within the productive apparatus. In the specific case of manufacturing industry in Mexico, the rapid trade liberalization and economic reforms implemented from the mid-1980s onwards fuelled a meagre modernization process, restricted to a very small number of activity classes generally engaged in global value chains. Although these "leading" activities in Mexico are governed by a very wide range of global corporate strategies that determine the type and level of relations they maintain with the domestic economy, among reflects the specific business interests of TNCS in the different locations, which could broadly be identified with the determinants of foreign direct investment (FDI), commonly detected by the economics literature (namely the search for markets, resources and assets, or the pursuit of efficiency) (UNCTAD, 1998; Mallampally and Sauvant, 1999). many other things, the fact is they tend to manufacture goods of low value-added and have weak linkages with the local economy.

In a context of extreme segmentation and dislocation of manufacturing processes worldwide, the characteristics of the leading activities of the Mexican manufacturing specialization model are explained by the proportion of temporary imports in the price of the goods produced, and by the undervaluation that $\mathrm{GCV}$ governance ${ }^{9}$ makes of the activities undertaken by their subsidiaries in the

\footnotetext{
9 Kaplinsky defines the concept of governance as the role of coordination and identification of dynamic income-earning opportunities, and the allocation of activities among the different participants in the productive process (Kaplinsky, 2000, p. 124).
} 
country. By manipulating the transfer prices at which intraenterprise transactions are undertaken, ${ }^{10}$ that governance generally reflects the benefits of the overall productive process in external locations. As noted by Katz (2004) for Latin America, there are close correlations between the presence of the subsidiaries of large transnational groups in the productive fabric, their low degrees of linkage owing to the vertical disintegration of these firms in their local operations, and the reduction of innovation efforts in the domestic economy.

Owing to the predominance of these organizational patterns in the "leading" activities, general productivity levels have largely stagnated, and the structure of manufacturing industry has become more heterogeneous as a result of trade liberalization - particularly in the first decade of this century according to the results of the exercise described this study. On this point, traditional dispersion statistics reveal increasing heterogeneity in the sector, both horizontally and vertically, which not only confirms the results obtained in the few studies available on the subject, but also makes it possible to update them in terms of time coverage and scope, thanks to the higher level of disaggregation at which the statistical exercises are applied.

In this regard, one of the key findings makes it possible to distinguish different growth rates in the types of heterogeneity identified, and everything seems to suggest that the within-sector form has expanded more slowly. One plausible hypothesis that future studies could corroborate is that the phenomenon reflects the progressive weakening of interlinkages in Mexico's manufacturing structure, resulting from its highly specialized nature. The tendency for productive activity to become more concentrated arises from these trends, having developed out of the recessionary conditions

\footnotetext{
10 A technical term commonly used in economics to refer to the transactions/exchanges undertaken between different enterprises belonging to a single firm or company. Often these enterprises are located in different countries and are subsidiaries of a single parent company based in an advanced country.
}

caused by the external debt crisis and inherent in the economic model established since the 1980s. Based on the stratification and polarization of the sector's structure, the concentration of supply in a few large firms in nearly all markets led to a rapid shake-out of productive plant and laid the foundations for widening productivity gaps between the different activities.

Another result that is strongly consistent with the signs referred to in previous studies is the zero contribution made by the reallocation of labour, in other words structural change, to the trend of productivity in Mexican manufacturing in the period 1994-2008. This is of crucial importance since one of the main theoretical assumptions used to argue in favour of the trade liberalization and economic deregulation strategy of the 1980s, was that the destruction of jobs in inefficient industries would be more than compensated by the creation of jobs in the "new" dynamic activities linked to international markets. Nonetheless, the evidence shows that the enterprises engaged in GVCs have not yet been able to generate permanent jobs or to transmit technological and organizational capacities to the rest of the productive fabric.

In brief, the elements mentioned above point to the progressive isolation of globalized activities within the structure, and they highlight the absence of dynamic economies of scale at the sector level, which is typical of structural change characterized as shallow in the Ocampo (2005) classification. ${ }^{11}$ In this context, the continuity and validity of the central concepts of the Latin American structuralist analysis would signal the need for growth planning that would reverse the trends observed, targeting the development of strategic industries with high potential for local integration, with a view to reconstructing domestic production chains.

\footnotetext{
11 The characteristic shallow structural transformation involves the development of export enclaves. This type of transformation is generally distinguished by the weakness of its complementarities (agglomeration and specialization economies) and of its learning processes (induced technological innovations). These two factors are crucial for raising productivity levels.
} 
Álvarez, M. (2002), "Cambios en la industria automotriz frente a la globalización: El sector de autopartes en México", Contaduría y Administración, No. 206, Mexico City, National Autonomous University of Mexico, July.

Arroyo, M. and M. Cárcamo (2010), "La evolución histórica e importancia económica del sector textil y del vestido en México", Economía y Sociedad, vol. 14, No. 25, Michoacán, Mexico, Universidad Michoacana de San Nicolás de Hidalgo, January/June.

BanXICO (Banco de México) (2011), "Estadísticas en línea. Índice de precios al productor" [online] http://www.banxico.org.mx/ SieInternet/consultarDirectorioInternetAction.do?accion $=\mathrm{co}$ nsultarDirectorioCuadros\&sector $=20 \&$ sectorDescripcion $=\%$ CDndices \%20de \%20Precios \%20Productor\%20y\%20de $\% 20$ Comercio\%20Exterior\&locale $=$ es.

Bielschowsky, R. (2009), "Sixty years of ECLAC: structuralism and neo-structuralism", CEPAL Review, No. 97 (LC/G.2400-P), Santiago, Chile, April.

Capdevielle, M. (2005), "Globalización, especialización y heterogeneidad estructural en México", Heterogeneidad estructural, asimetrías tecnológicas y crecimiento en América Latina, M. Cimoli (ed.), Santiago, Chile, Economic Commission for Latin America and the Caribbean (CEPAL)/Inter-American Development Bank (IDB).

Castañón, R., J.L. Solleiro and M. Del Valle (2003), "Estructura y perspectivas de la industria de alimentos en México", Comercio Exterior, vol. 53, No. 2, Mexico City, Bancomext, February.

Cimoli, M. (comp.) (2005), Heterogeneidad estructural, asimetrías tecnológicas y crecimiento en América Latina, Santiago, Chile, Economic Commission for Latin America and the Caribbean (ECLAC)/Inter-American Development Bank (IDB).

Cimoli, M. and G. Dosi (1995), "Technological paradigms, patterns of learning and development. An introductory roadmap", Journal of Evolutionary Economics, vol. 5, No. 3, Springer, October.

ECLAC (Economic Commission for Latin America and the Caribbean) (2007), "Progreso técnico y cambio estructural en América Latina", Project Document, No. 136 (LC/W.136), Santiago, Chile.

Fei, J. and G. Ranis (1961), Development of the Labour Surplus Economy: Theory and Policy, Homewood, Illinois, R.D. Irwin.

Furtado, C. (1963), "Capital formation and economic development", The Economics of Underdevelopment, A. Agarwala and S. Singh (eds.), New York, Oxford University Press.

(1962), Formación económica del Brasil, Mexico City, Fondo de Cultura Económica.

(1961), Desarrollo y subdesarrollo, Mexico City, Fondo de Cultura Económica.

Gereffi, G. (1995), "Global production systems and third world development", Global Change, Regional Response: The New International Context of Development, B. Stallings (comp.), New York, Cambridge University Press.

(1994), "The organization of buyer-driven global commodity chains: how U.S. retailers shape overseas production networks", Commodity Chains and Global Capitalism, G. Gereffi and M. Korzeniewicz (eds.), Wesport, Connecticut, Praeger.

Gereffi, G., J. Humphrey and T. Sturgeon (2005), "The governance of global value chains", Review of International Political Economy, vol. 12, No. 1, Taylor \& Francis, February.

Holland, M. and G. Porcile (2005), "Brecha tecnológica y crecimiento en América latina", Heterogeneidad estructural, asimetrías tecnológicas y crecimiento en América Latina, M. Cimoli (ed.), Santiago, Chile, Economic Commission for Latin America and the Caribbean (ECLAC)/Inter-American Development Bank (IDB).

INEGI (National Institute of Statistics and Geography) (2011a), Encuesta Industrial Mensual (EIM) (CMAP), 205 clases de actividad [online] http://dgcnesyp.inegi.org.mx/cgi-win/bdieintsi.exe/ NIVZ101290009000020002\#ARBOL (2011b), Encuesta Industrial Anual (SCIAN), 231 clases de actividad [online] http://dgcnesyp.inegi.org.mx/cgi-win/bdieintsi. exe/NIVR250130\#ARBOL.

Jorgenson, D. (1961), "The development of a dual economy", Economic Journal, vol. 71, No. 282, Wiley-Blackwell, June.

Kaplinsky, R. (2000), "Globalization and unequalisation: what can be learned from value chain analysis?", Journal of Development Studies, vol. 37, No. 2, Taylor \& Francis, December.

Katz, J. (2004), Industrial Dynamics, Innovation and Development, DRUID Summer Conference, Copenhagen.

Kupfer, D. and C. Rocha (2005), "Productividad y heterogeneidad estructural en la industria brasileña", Heterogeneidad estructural, asimetrías tecnológicas y crecimiento en América Latina, M. Cimoli (ed.), Santiago, Chile, Economic Commission for Latin America and the Caribbean (ECLAC)/Inter-American Development Bank (IDB).

Lewis, A. (1955), The Theory of Economic Growth, Homewood, Illinois, R.D. Irwin.

Maddison, A. (1952), "Productivity in an expanding economy", The Economic Journal, vol. 62, No. 245, Wiley-Blackwell, March.

Mallampally, P. and K. Sauvant (1999), "La inversión extranjera en los países en desarrollo", Finanzas y Desarrollo, vol. 36, No. 1, Washington, D.C., International Monetary Fund, March.

Mortimore, M. and W. Peres (2001), "Corporate competitiveness in Latin America and the Caribbean", CEPAL Review, No. 74 (LC/G.2135-P), Santiago, Chile, August.

Ocampo, J. (2005), "The quest for dynamic efficiency: structural dynamics and economic growth in developing countries", Beyond Reforms. Structural Dynamics and Macroeconomic Vulnerability, J. Ocampo (coord.), Washington, D.C., Stanford University Press.

Pinto, A. (1971), "El modelo de desarrollo reciente de la América Latina", El Trimestre Económico, vol. 38, No. 150, Mexico City, Fondo de Cultura Económica, April/June.

(1970), "Naturaleza e implicaciones de la "heterogeneidad estructural" de la América Latina", El trimestre económico, vol. 37, No. 145, Mexico City, Fondo de Cultura Económica. (1965), "Concentración del progreso técnico y de sus frutos en el desarrollo de América Latina", El Trimestre Económico, vol. 32, No. 125, Mexico City, Fondo de Cultura Económica.

Prebisch, R. (1962), "El desarrollo económico de la América Latina y algunos de sus principales problemas", Boletín económico de América Latina, vol. 7, No. 1, February.

Rodríguez, O. (1980), La teoría del subdesarrollo de la CEPAL, Mexico City, Siglo XXI.

Romero, J. (2009), "Medición del impacto de los acuerdos de libre comercio en América Latina: el caso de México", Estudios y Perspectivas series, No. 114 (LC/MEX/L.932), Mexico City, ECLAC subregional headquarters in Mexico. United Nations publication, Sales No. S.0X.II.G.107.

Singer, H. (1950), "The distribution of gains between investing and borrowing countries", The American Economic Review, vol. 40, No. 2, Nashville, Tennessee, American Economic Association, June.

unctad (United Nations Conference on Trade and Development) (1998), World Investment Report. Trends and Determinants (UNCTAD/wIR/1998), New York. United Nations publication, Sales No. E.98.II.D.5. 